$631.472 .8(477.43 / .44)$

\author{
. л м рчук \\ ьвівський н ціон льний університет імені в н \\ вул. . орошенк , 41, м. ввів, 79000, кр їн
}

ведено м кро- т мікроморфологічний опис грунту другої ф зи коршівського грунтоутворення. осліджено лише грунт другої ф зи, оскільки грунт першої ф зи сильно грегов ний бо його вз г лі нем у розріз $\mathrm{x}$ рим йлів т рмолинці.

бидв грунти другої ф зи коршівського грунтоутворення в меж $\mathrm{x}$ цих розрізів м ють спільні риси з суч сними чорнозем ми, проте відрізняються між собою умов ми формув ння.

лючові слов : мікроморфологічн будов , викопний грунт, лес, середній плейстоцен, грунтовий горизонт, шліф.

есово-грунтов серія н одільській височині м є суцільне поширення і скл дне чергув ння. цій території . огуцький провів дослідження, н підст ві яких розроблено лесово-грунтову серію для хідної кр їни $[1,2]$. окрем , досліджено розрізи рим йлів ( ернопільськ обл.) т рмолинці ( мельницьк обл.). они відобр ж ють почергове $з$ ляг ння лесових т п леогрунтових горизонтів. собливо яскр во тут предст влені відкл ди середнього плейстоцену. обох розріз х простежено певну спорідненість м кроморфологічної будови коршівського викопного грунтового комплексу. цих розріз х грунт другої ф зи коршівського грунтоутворення предст влений двом генетичними горизонт ми: гумусовим т ілюві льним. рунт першої ф зи інтенсивно грегов ний, іноді його вз г лі нем .

оршівський викопний грунтовий комплекс опорного розрізу рим йлів 3 ляг $є$ Н глибині 8,5-9,7 м. рунт другої ф зи коршівського грунтоутворення м є т кі особливості. оризонт потужністю 0,7 м скл дений щільними, безструктурними, безк рбон тними суглинк ми темно-сірого кольору з коричневим відтінком. нижній ч стині ш ру спостережено червоточини т зрідк - кротовини. ш рі б г то щільних вишневого т темно-сірого кольору з лізисто-м нг нових новоутворень ді метром до 3 мм і щільних темноз $б$ рвлених, м йже чорних плям гумусу ді метром до 2 см. о основи ш ру суглинки ст ють зернистими т дрібногрудкув тими світлішого (жовтув того) кольору. ерехід вузькоязикув тий. г то дрібних жилок-тріщин з втовшки 1-2 см т глибиною до 0,3-0,4 м (н повнення субвертик льне, н г дують “косми”).

оризонт потужністю 0,6 м розт шов ний близько до поверхні неогенових пісків. кл дений горизонт жовтув то-сірими дрібногрудкув тими суглинк ми (крупногрудкув тими в нижній ч стині ш ру), з червоточин ми, з повненими м тері лом горизонту . соляною кислотою суглинки не вз ємодіють. істять 6 г то кр пкових з лізисто-м нг нових новоутворень, хоч зрідк тр пляються конкреції ді метром до 3 мм. углинки щільні, оглеєні, вн слідок чого іноді з б рвлення м є зеленкув тий відтінок.

(C) л м рчук ., 2010 
рунт другої ф зи коршівського грунтоутворення в меж х опорного розрізу рмолинці з ляг є н глибині 6,7 м і м є потужність 0,9 м. оризонт потужністю 0,4 м скл дений темно-коричневими, безструктурними, м кропористими суглинк ми середніми до в жких. углинки інтенсивно з кип ють з соляною кислотою. они прониз ні тріщин ми, які з повнені перекривними лес ми. тріщин х т кож б г то дутиків. горизонті є велик кількість з лізисто-м нг нових прим зок, особливо у його нижній ч стині. нижній ч стині горизонту з фіксов н т кож н йбільш кількість червоточин, з повнених м тері лом горизонту . ерехід дрібнокосм тий, з зміною кольору.

оризонт грунту другої ф зи коршівського грунтоутворення м є потужність 0,5 м і скл дений суглинк ми легкими, жовтими з рудув тим відтінком, які вз ємодіють 3 соляною кислотою. углинки інтенсивно біогенно змінені, про що свідч ть кротовини т червоточини, з повнені м тері лом горизонту . кож у горизонті міститься велик кількість дутиків ді метром до 7 см. ерехід з зміною кольору н червонув то-бурий т грегов ністю.

ікроморфологічн будов грунту другої ф зи коршівського грунтоутворення опорного розрізу рим йлів м є т кі особливості.

оризонтові прит м нн гумусо-глинист оз лізнен пл зм основи сірого кольору з коричневим відтінком. ро оз лізненість свідч ть з лізисті ооїди (ді метром від 0,1 до 0,9 мм), конкреції т поч ткові форми мікроорштейнів (рис. 1, , б). кл дення пухке, грудкув те. грег ти скл дні (до третього порядку). лин ізотропн . ори великих розмірів (пон д 1 мм), х отично розт шов ні, нечисленні, проте їхня кількість дещо зрост є вниз по горизонту. рідк тр пляються пори у вигляді прямокутних к н лів. здовж стінок окремих пор простежено перекрист лізов ний к льцит, т кож п тьоки гумусу н вколо пор (див. рис. 1, в). інер льний скелет ст новить 25-30\% від площі шліф . ін предст влений зерн ми кв рцу $(0,01-0,02$ мм, великі зерн пон д 0,5 мм), к льциту (0,05-0,2 мм), у домішк $\mathrm{x}$ - рогов обм нк $(0,01-0,02$ мм), слюд (0,2 мм) (див. рис. 1, г). рг нічн речовин предст влен тонкодисперсним гумусом чорного кольору т гуміфіков ними рештк ми рослин, з 6 рвлення від бурого до чорного. рг нічні рештки розт шов ні головно поблизу пор. горизонті тр пляються гіфи грибів.

оризонт грунту другої ф зи коршівського грунтоутворення м є гумусово-глинисту пл зму основи коричневого кольору з сірим відтінком. горизонті 6 г то з лізистих конкрецій, виповнених зерн ми кв рцу (ді метр конкрецій - пон д 1 мм), мікроорштейнів т їхніх поч ткових форм (рис. 2, в, г). кл дення у вигляді злитих блоків (рис. 2, ). грег ти другого порядку. ори, як і в горизонті , великих розмірів, безсистемні, перев жно м ють поздовжній н прям. сто вздовж пор спостережено поздовжне орієнтув ння з лізисто-глинистої пл зми (у вигляді смуг (рис. 2, б)). лин перев жно ізотропн . інер льний скелет ст новить $20 \%$ від площі шліф . ерн кв рцу т к льциту приблизно одн кових розмірів - 0,01 мм, у домішк $\mathrm{x}$ - рогов обм нк (до 0,04 мм), зрідк тр пляються великі зерн обк т ного к льциту $(0,1$ мм). рг нічн речовин предст влен мулем. пор х виявлено грудкув ті скупчення гумусу з 6 рвленням від бурого до чорного. ля цього горизонту т кож х р ктерн н явність грибних гіфів.

ікроморфологічний н ліз шліфів грунту другої ф зи коршівського грунтоутворення опорного розрізу рмолинці відобр ж є т кі озн ки.

оризонт скл дений гумусово-глинистою пл змою сірого кольору з бурув тим відтінком. оризонт прониз ний з лізистими мікроорштейн ми ді метром до 0,3 мм. 

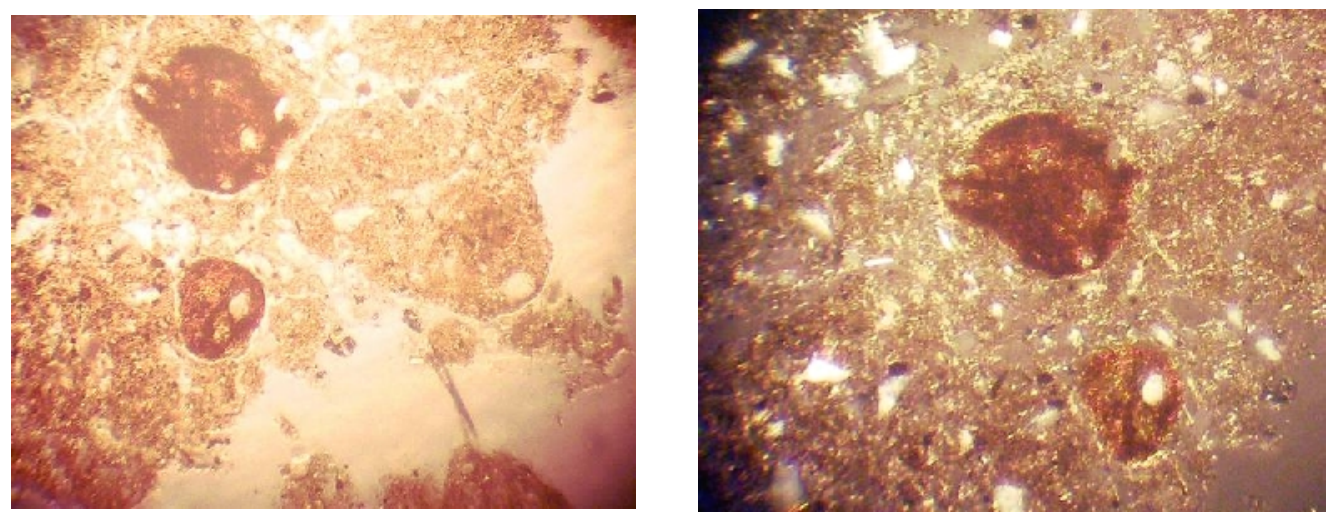

б
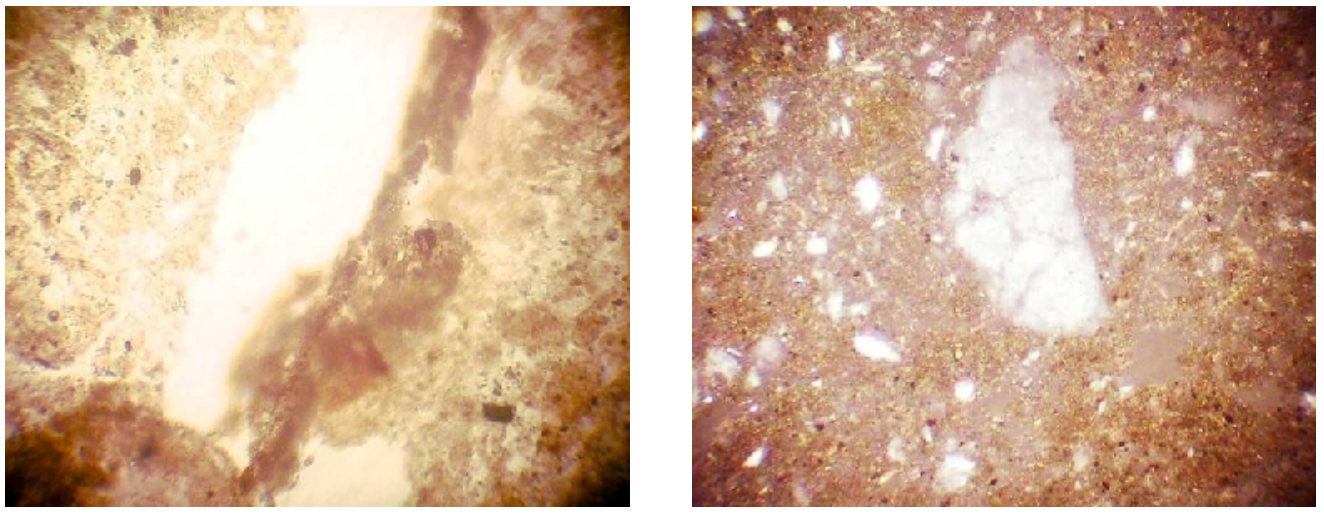

$\boldsymbol{B}$

ис. 1. оризонт грунту другої ф зи (розріз рим йлів). $\times 80$ : , в-ніколі ; б, г-ніколі + ; , $\sigma$ - поч ткові форми утворення з лізистих мікроорштейнів; $6-$ п тьоки гумусу вздовж пори; 2- мінер льний скелет.

ут т кож 6 г то поч ткових форм мікроорштейнів $(0,05$ мм) т з лізистих ооїдів розміром до 0,5 мм (рис. 3, в, г). кл дення пухке, грудкув те (див. рис. 3, ). грег ти скл дні, третього порядку. ори нечисленні, перев жно округлої форми. овкол окремих пор тр пляється перекрист лізов ний к льцит. г лом глин ізотропн, хоч н вколо стінок деяких пор орієнтув ння глини кр пч сте. інер льний скелет ст новить $25 \%$ від площі шліф (див. рис. 3, б). ін предст влений зерн ми кв рцу $(0,01-$ $0,02$ мм, великі зерн розміром до 0,1$),$ к льциту $(0,02)$, у домішк х - слюд $(0,02$ мм). рг нік предст влен мулем т гумон ми чорного з б рвлення. рідк тр пляються грибні гіфи.

оризонт м є гумусово-глинисту пл зму основи, з 6 рвлену в бурий з сірув тим відтінком колір. кл дення головно щільне, злите (рис. 4, в, г). грег ти прості, до другого порядку. ори поодинокі, прямі, схожі н тріщини висих ння; в окремих ділянк х шліфів спостережен невелик систем пор. здовж окремих пор виявлено п тьоки 

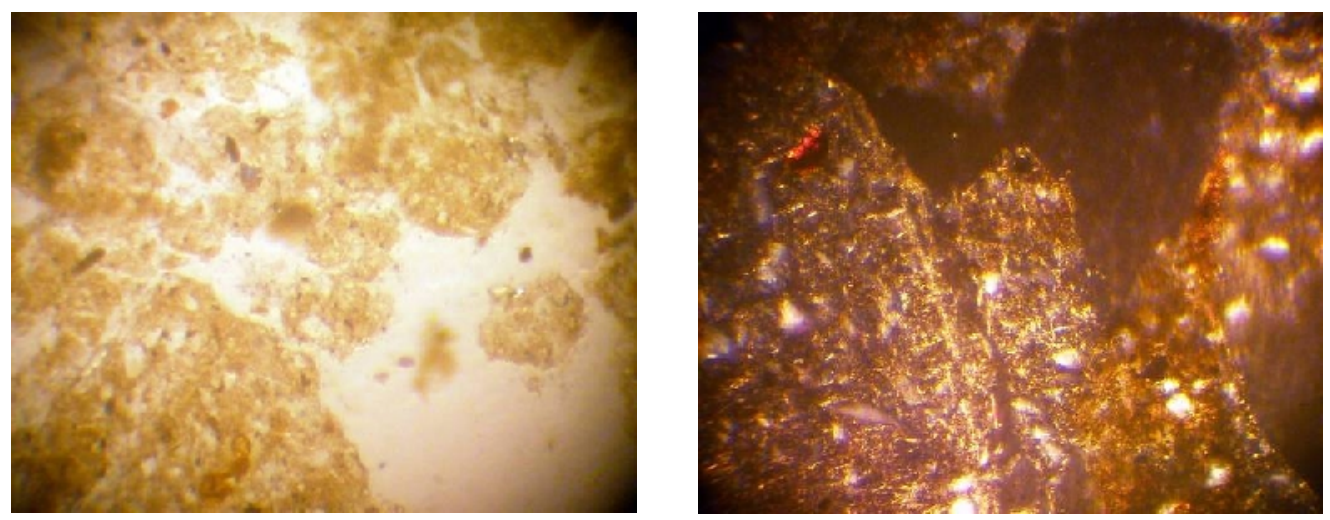

б
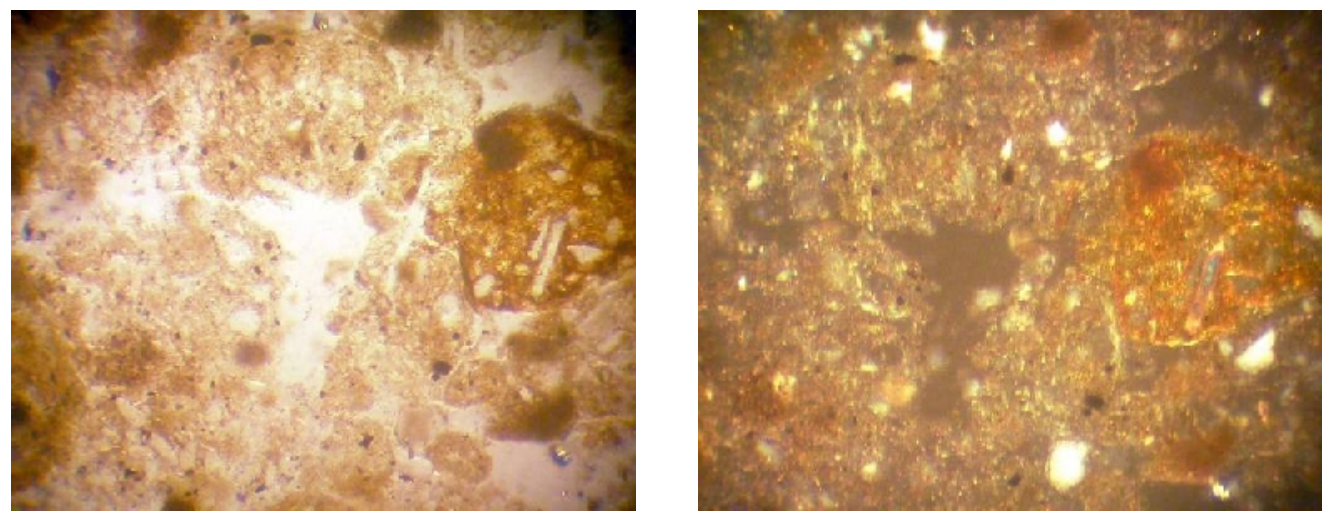

$\boldsymbol{B}$

2

ис. 2. оризонт грунту другої ф зи (розріз рим йлів). $\times 80$ : , в- ніколі ; б, г- ніколі +; - скл дення грунту; $\sigma$ - оптичне поздовжнє орієнтув ння глини; 6,2 - поч тков форм утворення мікроорштейну.

гумусово-глинистої речовини (див. рис. 4, б). рідк тр пляються з лізисті мікро-орштейни ді метром 0,5 мм. лин з г лом ізотропн, хоч н вколо окремих пор орієнтув ння глин кр пч сте. інер льний скелет ст новить від 15 до $25 \%$ площі шліф (див. рис. 4, ). ерн кв рцу розмір ми від 0,01 до 0,1 мм (великі, обк т ні) т К льциту (0,05 мм) ст новлять основу мінер льного скелет. еликі обк т ні зерн к льциту розт шов ні н вколо т всередині окремих пор. домішк х предст влені слюд (0,01 мм) і рогов обм нк (0,01 мм). рг нічн речовин - муль т гумони чорного кольору. кремі пори з повнені розкл деними орг нічними рештк ми.

тже, грунт другої ф зи коршівського грунтоутворення опорного розрізу рим йлів формув вся з умов н дмірного зволоження. ро це свідчить велик кількість рухомого $з$ ліз (яке концентрується в мікроорштейн х, ооїд х), т гумусу, як н слідок винесення гумусу у нижчі горизонти. ро н дмірні умови зволоження свідчить і огле- 

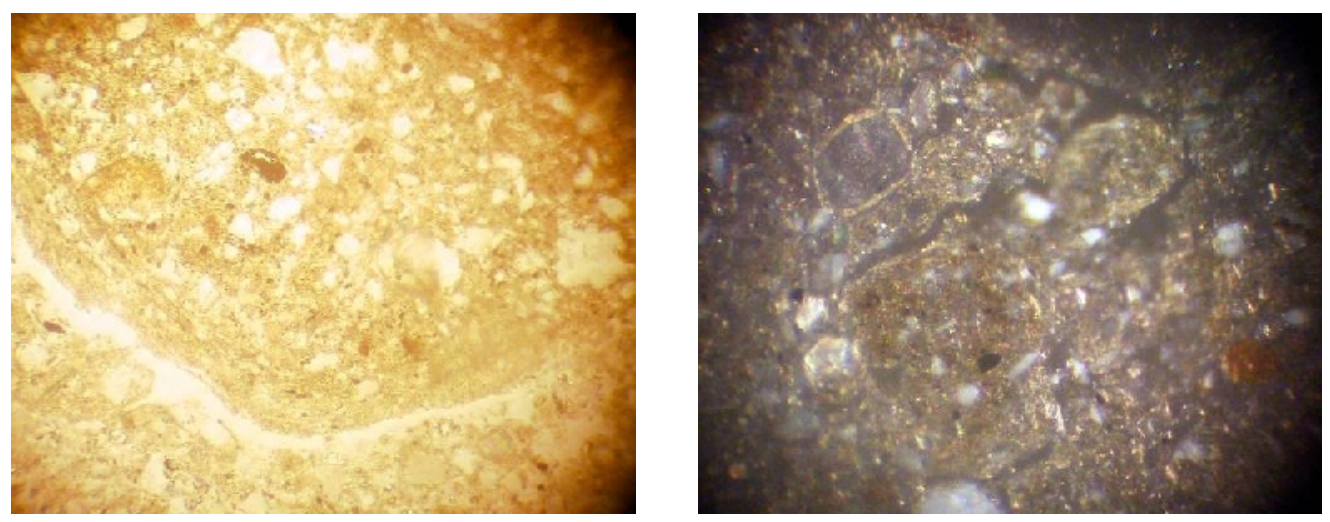

б
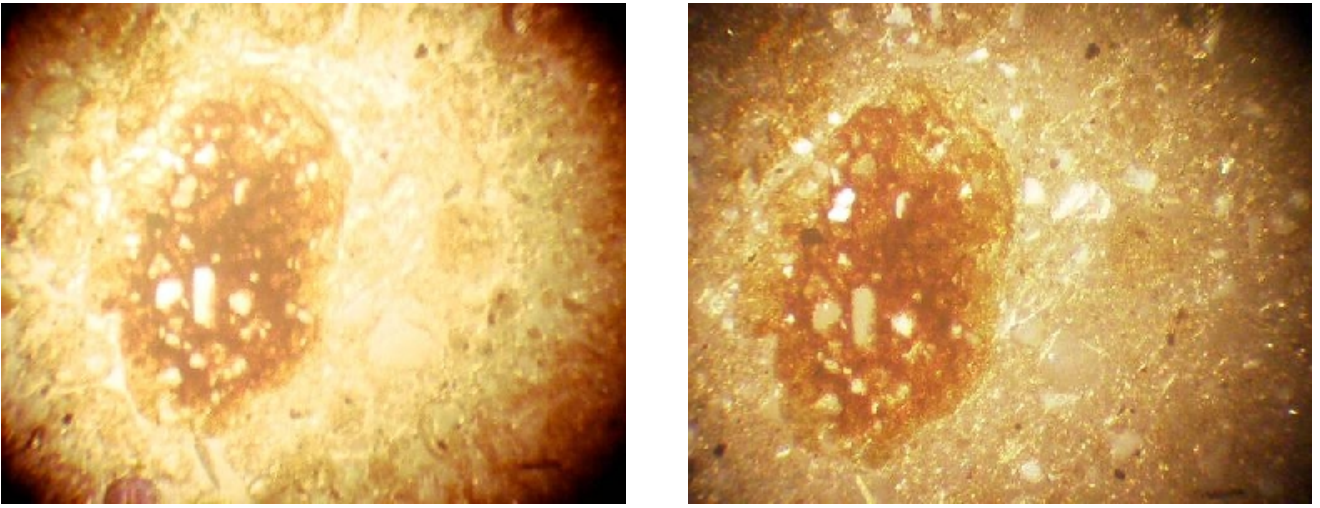

B

ис. 3. оризонт грунту другої ф зи (розріз рмолинці). $\times 80:$, в- ніколі ; 6, - ніколі +; - скл дення грунту; $\sigma$ - мінер льний скелет; $в$, г - з лізист конкреція.

єння (морфологічний опис). рунту вл стиве деяке вилуговув ння, хоч в обох горизонт х є озн ки перекрист лізов ного к льциту. явність скл дних грег тів у горизонті , гумус-муль, велик кількість орг нічних решток д ють підст ви припустити, що цей грунт схожий з рис ми із чорноземовими грунт ми. мовірно, грунт другої ф зи формув вся н дещо зниженій території, тоді можн припустити його спорідненість із суч сними лучно-чорноземними грунт ми.

ля грунту другої ф зи коршівського грунтоутворення опорного розрізу рмолинці т кож х р ктерн н явність руху орг ноглинистої речовини вниз по профілю. явність дутиків, вз ємодія з соляною кислотою (морфологічний опис розрізу) т перекрист лізов ний к льцит н вколо окремих пор д ють підст ви стверджув ти, що н Утворення грунту вплинули гідрогенно- кумулятивні процеси. рунту прит м нні риси суч сних к рбон тних чорноземових грунтів [3]. с ме: гумусово-глинист пл зм 

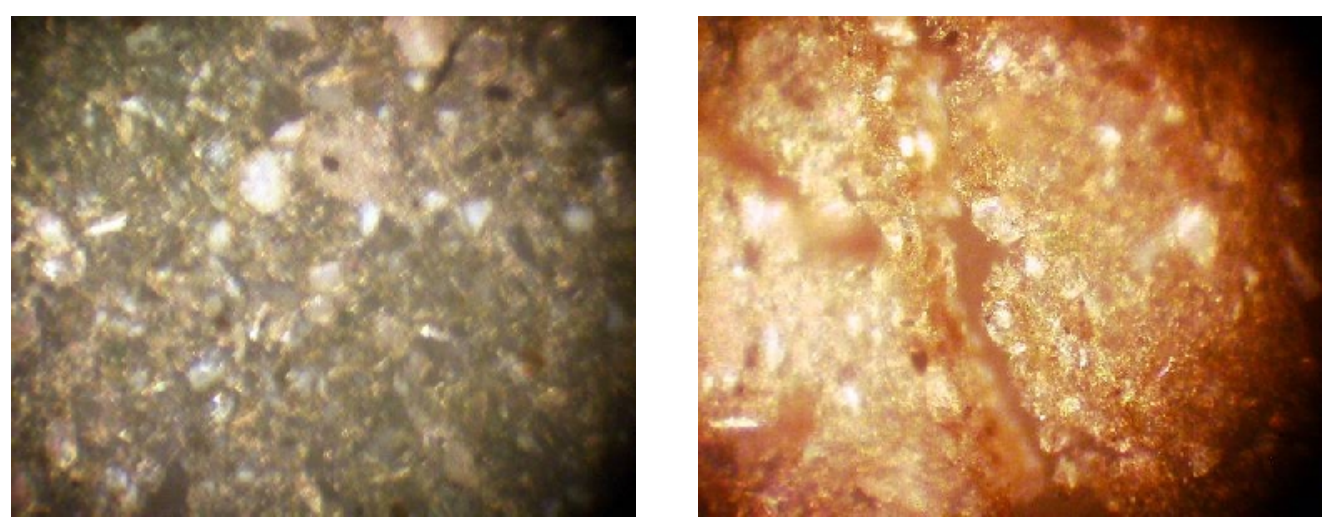

б

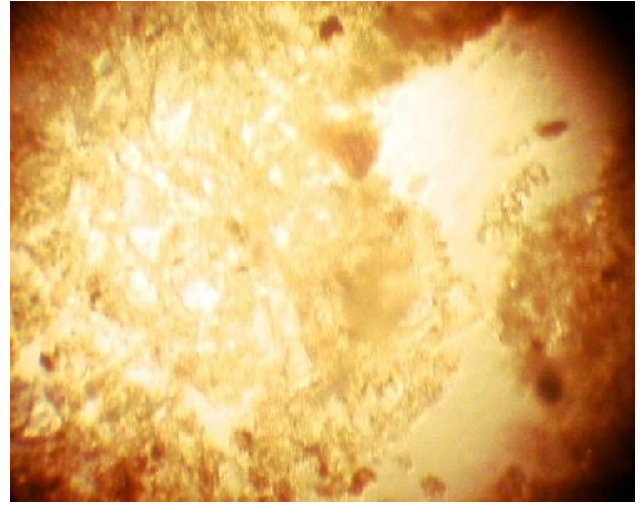

$\boldsymbol{B}$

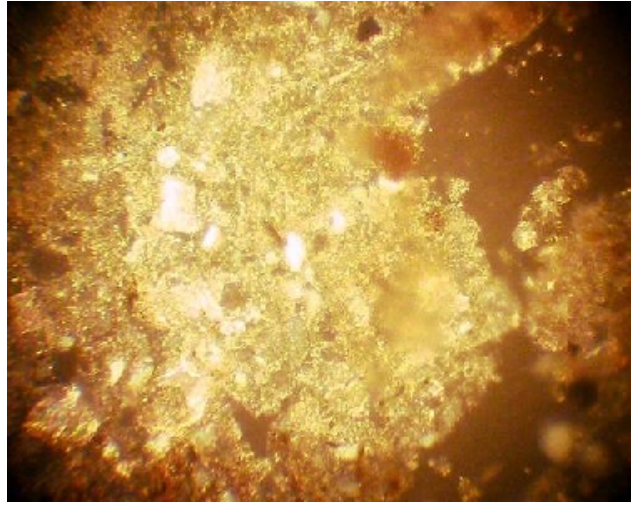

ис. 4. оризонт грунту другої ф зи (розріз рмолинці). $\times 80$ : , 6, г - ніколі +, в - ніколі ; - мінер льний скелет; $\sigma$ - скупчення гумусової речовини вздовж пори; 8,2 - скл дення грунту.

основи, скл дні грег ти у горизонті , велик кількість орг ніки, мікрокрист лічний перекрист лізов ний к льцит.

к б чимо, грунти другої ф зи коршівського грунтоутворення опорних розрізів рим йлів т рмолинці м ють спільні риси із суч сними чорноземовими грунт ми. роте умови формув ння цих грунтів дешо відрізнялись між собою. е д є змогу виділити умовну зон льність у поширенні грунту другої ф зи під ч с коршівського грунтоутворення н території одільської височини бо ж виокремити відмінності у рельєфі того ч су.

1. огуцкий . . нтропогеновые покровные отложения олыно- одолии // нтропогеновые отложения кр ины. иев, 1986. . 121-132. 
2. огуцкий . . сновные лессовые и п леопочвенные горизонты перигляци льной лессовопочвенной серии плейстоцен н юго-з п де осточно- вропейской пл тформы // тр тигр фия и корреляция морских и континент льных отложений кр ины. иев, 1987. .47-52.

3. рилов . ., елищев . ., едоров . . икроморфологическ я ди гностик некоторых элемент рных почвообр зующих процессов в почв х основных природных зон // еждун р. конгресс почвоведов. ., 1974. . 190-197.

\section{MICROMORPHOLOGICAL STRUCTURE OF THE SECOND PHASE OF THE KORSHIV FOSSIL SOIL FORMATION OF THE PODILLYA UPLAND}

\section{N. Palamarchuk}

Ivan Franko National University of Lviv, . Doroshenko St., 41, UA - 79000 Lviv, Ukraine

The article deals with the macro- and micromorphological description of the second phase of the Korshiv fossil soil formation. We investigated only the soil of the second phase because the soil of the first phase is destroyed or is not found in the Grymayliv and Yarmolyntci support slits.

So, the analyzed types of soil of the second phase in terms of these slits bear resemblance to modern black soil but differ in the conditions of their formation.

Key words: micromorphological structure, fossil soil, loess, Middle Pleistocene, soil horizon, thin section.

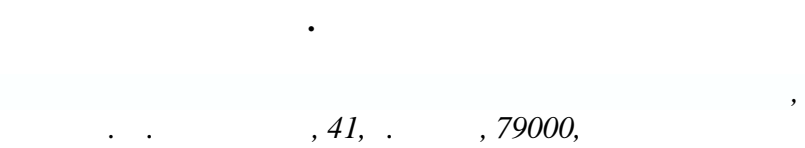

риведено м кро- и микроморфологическое опис ние почвы второй ф зы формиров ния коршевского ископ емого почвенного комплекс. сследов н только почв второй ф зы, поскольку почв первой ф зы сильно грегиров н или же отсутствует в р зрез х рым йлов и рмолинци.

бе почвы второй ф зы коршевского почвообр зов ния в предел х этих р зрезов имеют общие черты с современными чернозем ми, но отлич ются между собой условиями формиров ния.

лючевые слов : микроморфологическое строение, ископ ем я почв , лёсс, средний плейстоцен, почвенный горизонт, шлиф.

т ття н дійшл до редколегії 06.06.2009

рийнят до друку 20.09.2009 